\title{
РАЗВИТИЕ СОЦИАЛЬНО-ПРОФЕССИОНАЛЬНЫХ КОМПЕТЕНЦИИ СОТРУДНИКОВ ПОЛИЦИИ В СОВРЕМЕННЫХ УСЛОВИЯХ ГЕОПОЛИТИЧЕСКИХ ТРАНСФОРМАЦИИ
}

\section{DEVELOPMENT OF SOCIAL AND PROFESSIONAL COMPETENCE OF POLICE OFFICERS IN MODERN CONDITIONS OF GEOPOLITICAL TRANSFORMATIONS}

\section{E. Zhigalova}

Summary: The article substantiates the problem of increasing the level of competence of the police of the Russian Federation in the conditions of modern social and geopolitical challenges. This problem is correlated by the author, on the one hand, with the state concept of national security; on the other hand, with the understanding of the need for an adequate response of society to negative social transformations caused, inter alia, by the pandemic situation, the emergence of new types of offenses, the intensification of destructive actions. In these conditions, the solution is seen in the consolidation of civil society, constructive dialogue and cooperation of citizens with the police. This can only be ensured by improving the quality of the work of police officers themselves, developing their social and professional competencies. The article presents the characteristics of these competencies; analyzes the existing problems of their formation, notes the optimal, in the author's opinion, ways to solve them.

Keywords: national security, modern challenges, civil consent, police, social and professional competencies.

\author{
Жигалова Евгения Александровна \\ Н.с., Восточно-Сибирский институт МВД России, \\ 2. Иркутск \\ razr15@rambler.ru
}

Аннотация: В статье обоснована проблема повышения уровня компетентности полиции Российской Федерации в условиях современных социальных и геополитических вызовов. Данная проблема соотнесена автором, с одной стороны, с государственной концепцией национальной безопасности; с другой стороны, с пониманием необходимости адекватного реагирования общества на негативные общественных трансформации, обусловленные, в том числе, ситуацией пандемии, появлением новых видов правонарушений, активизацией деструктивных действий. В этих условиях выход видится в сплочении гражданского общества, конструктивном диалоге и сотрудничестве граждан с органами полиции. Обеспечить это может только повышение качества работы самих сотрудников полиции, развитие их социальных и профессиональных компетенций. В статье представлена характеристика данных компетенций; проанализированы существующие проблемы их формирования, отмечены оптимальные, на взгляд автора, пути их решения.

Ключевые слова: национальная безопасность, вызовы современности, гражданское согласие, полиция, социальные и профессиональные компетенции.
Последние годы являются серьёзным вызовом российским гражданам как органичной части геополитического сообщества. Пандемия, охватившая весь мир, не только обусловила экономические и логистические сложности, негативные геополитические трансформации, но и спровоцировала ряд дестабилизирующих действий в российском обществе. К ним относятся призывы отдельных граждан и групп не доверять решениям правительства, противостоять им; попытки дискредитировать государственный аппарат и силовые структуры; повторяющиеся «вбросы» на уровне отдельных СМИ и социальных сетей провокационной информации; появление новых форм мошенничества, активизация призывов к общественным беспорядкам [см., например,1].

В этой связи задачей полиции как государственного института, реализующего функции защиты общественной безопасности, является конструктивное, снимающее социальную напряжённость профессиональное выпол- нение своих задач. На это нацеливает также Стратегия национальной безопасности Российской Федерации, где поддержка национального согласия, гражданского диалога называется фактором внутренней безопасности государства, сохранения собственно государственности [2]. Не случайно до сих пор является актуальным высказывание знаменитого русского историка, писателя H.М. Карамзина о том, что «государству для его безопасности нужно не только физическое, но и нравственное могущество» [3, с. 36]. Это могущество может быть достигнуто совместными усилиями и ценностными социальными установками граждан и представителей государства.

Проблема организации позитивного диалога граждан и государства, повышения доверия к сотрудникам полиции как представителям государства, уполномоченным им обеспечивать общественную безопасность, активно представлена в научном дискурсе [см., например, 
$4,5,6]$. Появились и серьёзно обсуждаются общественностью такие вопросы и понятия, как «кредит доверия к полиции», «действия полиция в условиях самоизоляции», «самоорганизующееся гражданское общество», «правовое государство», «общественная легитимность сотрудников полиции» и др. При этом неоднократно высказываются пожелания повысить уровень социально-профессиональной компетентности сотрудников ОВД, под которой понимается «способность на основе законодательства Российской Федерации качественно и профессионально осуществлять защиту жизни, здоровья, прав и свобод граждан, обеспечивая общественную безопасность» [7, с.61].

По мнению автора, большое значение имеет целенаправленная работа вузов системы МВД по повышению качества подготовки не только курсантов, будущих офицеров полиции, но и действующих сотрудников ОВД на краткосрочных курсах обучения в рамках программы целевой профессиональной подготовки граждан, впервые принятых на службу в систему МВД. В данный относительно небольшой временной период подготовки нужно обеспечить развитие, прежде всего, социальных компетенций сотрудников полиции, которые непосредственно общаются с людьми, формируя имидж государственной правовой системы в обществе. Социальная ориентированность деятельности сотрудников МВД утверждена также законодательно и отражена в нормативных правовых актах, в частности, в Указе Президента Российской Федерации от 24 декабря 2009 г. № 1468 «О мерах по совершенствованию деятельности органов внутренних дел Российской Федерации» [8] и Законе «О полиции» [9].

Социальная ориентированность профессиональной деятельности хорошо обоснована рядом представителей классической зарубежной социологи. Так, американский учёный-социолог Ф.Г. Гиддингс связывает воедино понятия «социум», «социализация» и «социальные навыки (компетенции)», которыми, на его взгляд, обеспечивается успешная деятельность личности в социальной среде [10]. Т. Парсонс, в сою очередь, считает, что социализация соотнесена с ценностями общества и нормами взаимодействия в социальной и профессиональной среде [11]. В определении социализации А. Дж. Баама также подчёркнута взаимосвязь социального опыта деятельности с ценностями социума [12].

Анализ литературы и общественных тенденций в контексте рассматриваемой проблемы, а также проведённое автором в 2019-2021 годах целенаправленное исследование позволили обосновать взаимосвязь социальных и профессиональных компетенций современного сотрудника полиции и включить в их трактовку: 1) знание психологических и коммуникативных особенностей поведения в типовых проблемных ситуациях вза- имодействия с гражданами; 2) чёткое понимание круга полномочий в сфере профессиональной и социальной деятельности; навык информационного просвещения в сложных условиях геополитических процессов; 3) развитое гражданско-правовое сознание; 4) ответственные, гуманные, уважительные действия по отношению к людям, основанные на эмоционально-волевой саморегуляции; 5) понимание и поддержку нравственных принципов человеческой безопасности, обоснованное применение специальных средств; 6) толерантность и грамотное поведение с учётом этнических и конфессиональных традиций граждан России как представителей многонационального государства и др.

Комплексная первоначальная диагностика слушателей краткосрочных курсов вузов МВД, осуществлённая на базе Восточно-Сибирского института МВД России и включающая 97 респондентов, выявила следующие проблемы, не позволяющие говорить о достаточном уровне сформированности социально-профессиональных компетенций у действующих сотрудников ОВД:

- 59,17\% респондентов не понимают и не могут объяснить суть общественного диалога между гражданами и представителями власти - сотрудниками полиции; а также роль общественного диалога в собственной профессиональной деятельности;

- 28,34\% слушателей признали готовность уехать из страны на постоянное место жительства с возможным изменением рода деятельности;

- большинством слушателей недооценивается роль духовно-нравственных качеств сотрудника полиции, более 73,67 \% респондентов согласны с утверждением о недостаточном уровне социально-профессиональных компетенций и нравственности поведения у сотрудников полиции;

- 38,52\% респондентов продемонстрировали высокий уровень агрессивности, а понимание роли эмоционально-волевой регуляции при этом отмечено только у 29,57\% слушателей;

- при тестировании слушателей по методике В. Синявского и Б.А. Федоришина у каждого третьего из респондентов отмечены проблемы при общении с людьми; при этом вызывает тревогу тот факт, что взаимодействие с людьми, необходимость выстраивания диалога у многих респондентов даже вызывает раздражение.

Результатами первоначальной диагностики было ещё раз подтверждено значение целенаправленной работы по развитию социально-профессиональных компетенций сотрудников полиции, без чего не могут быть обеспечены как их качественная профессиональная деятельность, так и помощь граждан в поддержании общественного порядка, защите личной и общественной безопасности. 
В качестве меры обеспечения повышения социально-профессиональной компетентности слушателей краткосрочных курсов вузов системы МВД был предложен к реализации потенциал интерактивных форм и методов обучения на основе применения особых (в виде диалога и полилога) форм учебного взаимодействия на осях «слушатель-слушатель», «слушатель-группа», «подгруппа-подгруппа», «слушатель-компьютер», «слушательвиртуальный тренажёр» и т.п. Эти направления были реализованы в ходе применения авторского тренинга конструктивного общения, использования баскет-метода, кейс-стади, имитационных игр, возможностей виртуальной визуализации и т.п.

Большое значение, по отзывам слушателей имела работа по учебным подгруппам в целях осуществления подробного анализа (с элементами проигрывания и обязательного обоснования) ситуаций общения с гражданами в контексте того или иного происшествия, моделируемого или типичного правонарушения и т.п. Высокую оценку у слушателей получило применение на занятиях по криминалистическим исследованиям специального электронного кейса, включающего специальные обучающие и тестовые компьютерные программы, видеофильмы и т.п. Особый интерес вызвало применение специализированных программ, помогающих отработать навык обнаружения специфических «цифровых следов», что является на сегодняшний день очень значимым аспектом компетентности, помогающим упредить различные виды компьютерного мошенничества, возросшего как явление в ситуации пандемии и вынужденной изоляции граждан, особенно пожилого возраста [13]. Немаловажное значение имела также методическая помощь (в рамках проблемного семинара и пяти онлайн-консультаций) преподавателям курсов в создании собственных учебных электронных кейсов в целях применения ИКТ технологий для обучения слушателей, повышения их компетентности.
Проведённая по окончании формирующего эксперимента контрольная диагностика подтвердила результативность применения предложенных форм и методов интерактивного обучения. И, таким образом, по итогам исследования сделаны следующие выводы:

- в условиях геополитических вызовов, таких, как пандемия, разрушение привычного уклада жизни граждан, замена реального социального взаимодействия виртуальным, появления, в связи с этим, новых видов социального противостояния, правонарушений и т.п. как никогда возрастает роль общественной безопасности, обеспечиваемая профессиональными действиями сотрудников полиции;

- профессиональная компетентность сотрудника полиции на сегодняшний день неотделима от его социальных умений, в том числе, умений выстраивать конструктивный общественный диалог, привлекать граждан к сотрудничеству, повышая имидж полиции в глазах населения, всячески способствуя укреплению доверия между обществом и властью;

- развитие таких социально-профессиональных компетенций выходит на первый план в контексте решения проблем повышения качества образовательного процесса в вузах системы МВД, в том числе, и на краткосрочных курсах обучения сотрудников, впервые приступивших к служебной деятельности в рядах полиции;

- большой, не реализованный в полной мере потенциал имеют интерактивные формы и методы обучения, обусловливающие развитие социально-профессиональных компетенций на основе диалога и полилога, заставляющие слушателей думать, анализировать, обсуждать варианты, корректно обосновывать свою точку зрения, убеждать, выстраивать, в целом, конструктивное профессиональное и социальное взаимодействие.

\section{ЛИТЕРАТУРА}

1. Аналитическая записка Глобальной инициативы против транснациональной организованной преступности «Преступность и инфекция. Воздействие пандемии на организованную преступность». URL: https://мвд.pф/upload/site1/folder_page/019/882/802/Globalnaya_initsiativa._Prestupnost_i_ Infektsiya1.pdf (дата обращения: 25.08.2021).

2. Указ Президента Российской Федерации от 02.07.2021 № 400 «0 Стратегии национальной безопасности Российской Федерации». URL: http://static.kremlin.ru/media/events/files/ru/QZw6hSk5z9gWq0plD1ZzmR5cEROg5tZC.pdf (дата обращения: 25.08.2021).

3. Карамзин Н.М. Записка о древней и новой России в ее политическом и гражданском отношениях [предисл., подгот. текста и примеч. Ю.С. Пивоварова]. М.: Наука, 1991. 125 c.

4. Чернявская К.О. Доверие граждан к полиции как предпосылка безопасности личности и общества в государстве// Безопасность личности, общества и государства: теоретико-правовые аспекты. Сборник тезисов выступлений участников международной научно-теоретической конференции [сост.: А.В. Афанасьев, А.В. Ефимовский, О.С. Кравченко]. Санкт-Петербург, 2019. С. 729-732.

5. Ханин С.В. Система критериев эффективности взаимодействия полиции и общества в интересах обеспечения общественной безопасности// Юридическая наука и практика: Вестник Нижегородской академии МВД России. 2019. № 3 (47). С. 66-72.

6. Степанченкова Е.В. Принцип общественного доверия и поддержки граждан как основа взаимодействия полиции и общества при осуществлении право- 
охранительной деятельности // Молодой ученый. 2020. № 18 (308). С. 333-335.

7. Шацкая Е.А. Профессионализм и компетентность сотрудников ОВД // Полицейская деятельность. 2020. № 3.С.61-69

8. Указ Президента РФ от 24.12.2009 № 1468 (ред. от 01.03.2011) "0 мерах по совершенствованию деятельности органов внутренних дел Российской Федерации".URL: http://www.consultant.ru/document/cons_doc_LAW_95462 (дата обращения: 25.08.2021).

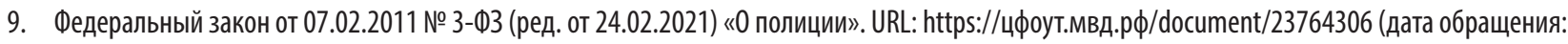
25.08.2021).

10. Giddings, F.H. The Principles of Sociology : An Analysis of the Phenomena of Association and of Social Organization. 3rd edn. N.Y.;L.: MacMillan \& Co., 1896. Ltd. XXVI. $476 \mathrm{p}$.

11. Parsons T. Essays in sociological theory. Glencoe: The Free Press; London: Collier-Macmillan Ltd., 1964. 459 p.

12. Bahm A.J. Why be moral? New Mexico. Albuquerque : World books, 1992. $435 \mathrm{p}$.

13. Спекуляция пандемией, как преступники используют кризис COVID-19 // Отчёт Европола, март 2020 г. URL: https://mvd.ru/upload/site1/folder_page/019/882/802/Evropol_Spekulyatsiya_pandemiey1.pdf (дата обращения: 25.08.2021).

() Жигалова Евгения Александровна (razr15@rambler.ru).

Журнал «Современная наука: актуальные проблемы теории и практики»

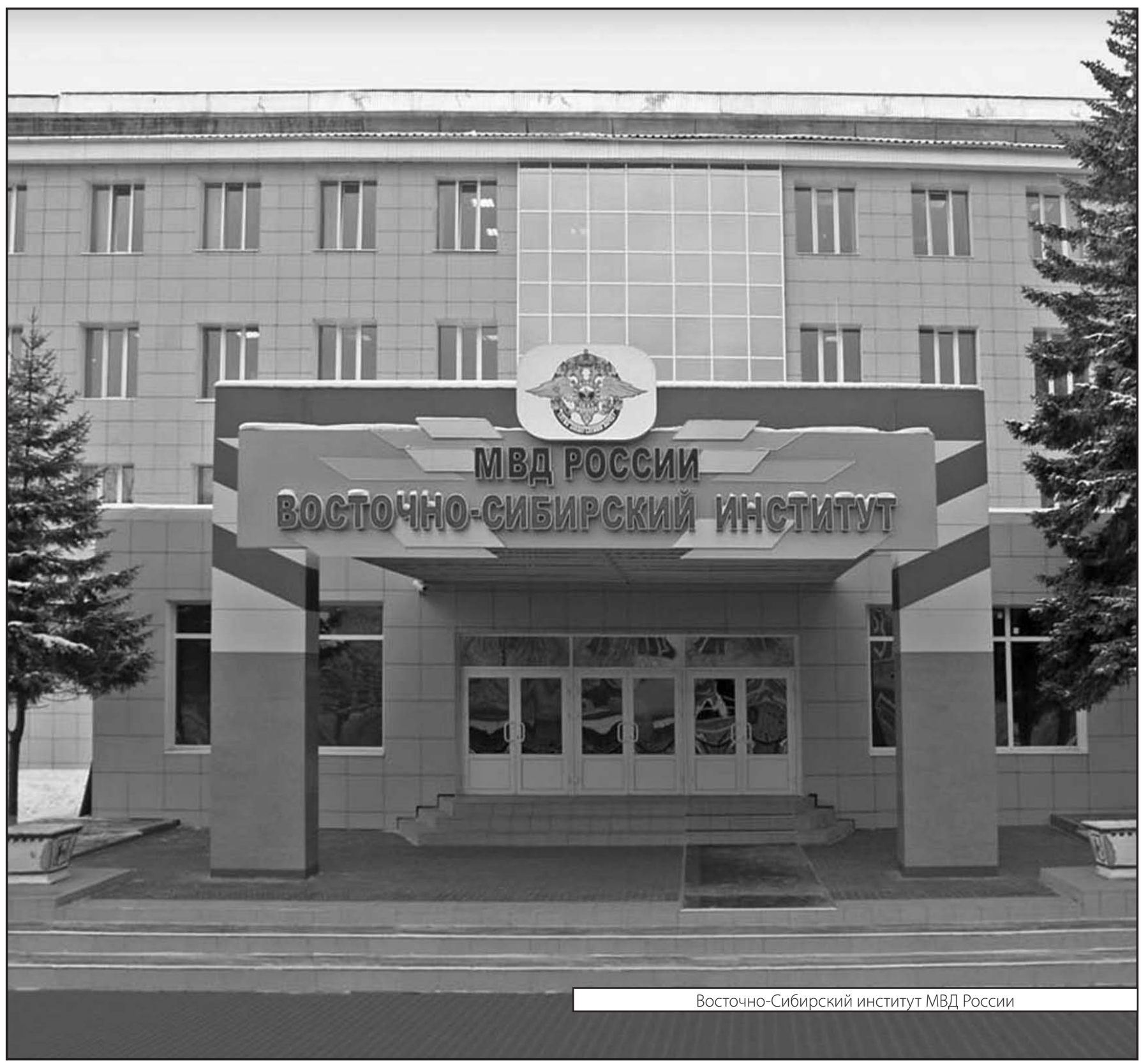

